\title{
EVALUASI PENGELOLAAN SISTEM PENYEDIAAN AIR BERSIH DI PDAM KOTA MADIUN
}

\author{
Yustika Kusumawardani ${ }^{1)}$, Widi Astuti ${ }^{2)}$ \\ Universitas Pandanaran \\ Jalan Banjarsari Barat No.1 Pedalangan, Banyumanik, Semarang, Indonesia \\ e-mail ${ }^{1)}$ : tika.ytika@gmail.com \\ e-mail ${ }^{2}$ : widi_unp@yahoo.co.id
}

\begin{abstract}
ABSTRAK
Kota Madiun merupakan daerah dengan laju pembangunan cukup pesat sehingga diperlukan pengelolaan air bersih yang optimal untuk memenuhi tingkat kebutuhan penduduknya. Kebutuhan air bersih Kota Madiun seluruhnya dipenuhi dengan sistem perpipaan. Keseluruhan sistem penyediaan air di Kota Madiun berasal dari sumur dalam. Tingkat pelayanan penduduk di PDAM Kota Madiun masih di bawah kriteria ideal. Pengelolaan sistem penyediaan air bersih yang kurang optimal, diduga akan mempengaruhi tingkat pelayanan air bersih Kota Madiun. Oleh karena itu diperlukan evaluasi pengelolaan sistem penyediaan air bersih agar dapat meningkatkan pelayanan air bersih di Kota Madiun. Metode yang digunakan dalam penelitian ini adalah melalui tinjauan langsung, wawancara, dan studi literatur. Dari hasil evaluasi, pengelolaan sistem transmisi PDAM Kota Madiun masih kurang karena tidak terdapat jalur yang jelas dan pemeliharaannya tidak terawasi secara keseluruhan. Kapasitas reservoir sudah mencukupi kebutuhan cadangan air dan penyediaan air bersih. Sistem distribusi PDAM Kota Madiun belum dapat menerapkan sistem zoning karena beberapa sumur dalam langsung difungsikan sebagai pemasok air menuju daerah di sekitar lokasi sumur. Tekanan air juga kurang diperhatikan sehingga dibeberapa wilayah pelayanan tekanan air masih kurang.

Kata Kunci: evaluasi sistem penyediaan air, sistem transmisi, reservoir, sistem distribusi, PDAM Kota Madiun

\section{ABSTRACT}

Madiun city was an area with a rapid rate of development so it needs optimal clean water management to meet the level of population needs. Piped water systems were utilized by utilizing raw water sources from deep wells. The entire water supply system in Madiun City comes from deep wells. The level of population service in PDAM Kota Madiun was still under ideal criteria. Management of water supply system that was less optimal, allegedly will affect the level of municipal water services Madiun. It was therefore necessary to evaluate the management of water supply system in order to improve the clean water service in Madiun City. The method used in this research was through direct reviews, interviews, and literature studies. From the evaluation result, management of PDAM Madiun transmission system was still lacking because there was not clear path and maintenance was not supervised as a whole. The reservoir capacity was sufficient for water supply and clean water supply. The distribution system of PDAM Kota Madiun has not been able to implement zoning system because some deep wells are functioned as water supplier to the area around the well location. Water pressure was also less attention so that some areas of water pressure services were still lacking.
\end{abstract}

Keywords: evaluation of water supply system; transmission system; reservoir; distribution system; PDAM Kota Madiun 


\section{PENDAHULUAN}

Peningkatan eksploitasi sumber air bersih yang berasal dar air tanah jika tidak diatur dengan baik, maka akan menimbulkan degradasi kualitas dan kuantitas air bersih. Oleh karena itu manajemen pengelolaan air bersih menjadi sangat penting. Manajemen pengelolaan air bersih mencakup pengolahan sumber air baku, pengaliran serta pembagian air bersih sampai ke wilayah pelayanan. Sistem pengelolaan sumber daya air secara terpadu akan mampu memberikan pasokan air yang lebih adil bagi konsumen. Penyelenggaraan sistem penyediaan air bersih di Indonesia pada umumnya dilaksanakan oleh Perusahaan Daerah Air Minum (PDAM).

Kota Madiun merupakan salah satu kota dari $38 \mathrm{kota} / \mathrm{kabupaten}$ di provinsi Jawa Timur. Kota Madiun yang dilalui Sungai Madiun, berada sekitar $30 \mathrm{Km}$ di sebelah selatan pertemuan antara Sungai Madiun dengan Bengawan Solo. Secara topografi Kota Madiun bagian Selatan mempunyai ketinggian sekitar $67 \mathrm{~m}$ diatas permukaan laut $(\mathrm{dpl})$ dan makin ke Utara menurun sampai $64 \mathrm{~m}$ dpl dengan kemiringan rata-rata $0-2 \%$. Kota Madiun merupakan salah satu daerah dengan laju pembangunan yang cukup pesat sehingga diperlukan ketersediaan air bersih yang memadai. Pengelolaan air bersih yang optimal diperlukan untuk memenuhi tingkat kebutuhan penduduknya secara berkesinambungan.

Kebutuhan air bersih Kota Madiun seluruhnya dipenuhi dengan memanfaatkan air baku yang semuanya berasal dari sumur dalam. Keseluruhan dari sistem penyediaan air di Kota Madiun berasal dari sumur dalam dan Sistem perpipaan diusahakan oleh PDAM Kota Madiun. Tingkat pelayanan penduduk di PDAM Kota Madiun masih di bawah kriteria ideal. Jumlah pelanggan air PDAM masih tergolong kurang dibandingkan jumlah keseluruhan penduduk kota Madiun. Pengelolaan sistem penyediaan air bersih yang kurang optimal, diduga akan mempengaruhi tingkat pelayanan air bersih Kota Madiun. Oleh karena itu diperlukan evaluasi pengelolaan sistem penyediaan air bersih agar dapat meningkatkan pelayanan air bersih di Kota Madiun.

Makalah ini akan memberikan gambaran mengenai pelaksanaan pengelolaan sistem penyediaan air bersih di Kota Madiun. Dimana PDAM Kota Madiun yang bertindak sebagai perusahaan penyedia jasa pelayanan dibidang air minum. PDAM Kota Madiun dibutuhkan masyarakat perkotaan untuk mencukupi kebutuhan air bersih yang layak dikonsumsi. Evaluasi yang dilakukan dalam sistem pengelolaan air tersebut meliputi pengelolaan sumber air baku, pengolahan, dan sistem penyalurannya

\section{KAJIAN PUSTAKA}

\section{Sistem Penyediaan Air Minum}

Berdasarkan Peraturan Pemerintah

Republik Indonesia Nomor 122 Tahun 2015 tentang Sistem Penyediaan Air Minum, yang dimaksud dengan air baku adalah air yang berasal dari sumber air permukaan, air tanah, air hujan dan air laut yang memenuhi baku mutu tertentu sebagai Air Baku untuk Air Minum. Sistem penyediaan air biasanya terdiri dari : pengumpulan air, pengolahan air, sistem transmisi dan sistem distribusi. Aktivitas pengolahan air sangat dibutuhkan ketika kualitas dari air yang disadap tidak memenuhi standar kualitas air minum, sehingga tujuan dari pelayanan air minum masih dapat terpenuhi. Aktivitas sistem transmisi adalah mengumpulkan dan menyalurkan air dari sumber ke pengolahan air. Sedangkan sistem ditribusi adalah mendistribusikan air tersebut kepada pelanggan dengan volume dan tekanan yang memenuhi.

Sistem penyediaan air bersih harus dapat menyediakan jumlah air yang cukup untuk kebutuhan suatu kota. Unsur-unsur sistem yang modern terdiri atas : sumber air baku, fasilitas penyimpanan, fasilitas transmisi ke unit pengolahan, fasilitas pengolahan, fasilitas transmisi dan penyimpanan, dan fasilitas distribusi. Dalam rangka mengatasi permasalahan dalam bidang air bersih, diperlukan adanya suatu kriteria perencanaan untuk menjaga mutu sistem yang akan dibangun dengan strategi dan pengembangan kota.

\section{Sistem Transmisi dan Reservoir}

Sistem perpipaan transmisi bertujuan untuk menyalurkan air dari sumber air baku misalnya, mata air menuju ke bangunan pengolahan, serta mengalirkan sumber air baku menuju ke reservoir induk. Sistem transmisi air bersih dapat dilakukan dengan beberapa cara tergantung kondisi topografi yang menghubungkan sumber air dengan reservoir. 
Sistem perpipaan yang digunakan tergantung topografi dari wilayahnya, dan dapat dilakukan secara gravitasi, pemompaan maupun kombinasi pemompaan dan gravitasi (Peavy, 1985)

Reservoir digunakan dalam sistem distribusi untuk menyeimbangkan debit pengaliran, mempertahankan tekanan, dan mengatasi keadaan darurat. Untuk optimasi penggunaan, reservoir harus diletakkan sedekat mungkin dengan pusat daerah pelayanan. Di kota besar, reservoir distribusi ditempatkan pada beberapa lokasi dalam daerah pelayanan. Reservoir distribusi juga digunakan untuk mengurangi variasi tekanan dalam sistem distribusi (Fair dkk., 1986).

\section{Sistem Distribusi}

Sistem distribusi adalah sistem yang langsung berhubungan dengan konsumen, yang mempunyai fungsi pokok mendistribusikan air yang telah memenuhi syarat ke seluruh daerah pelayanan. Sistem ini meliputi unsur sistem jaringan perpipaan dan sarana pelengkapnya seperti, hidran kebakaran, pelepas tekan, sistem pemompaan (bila diperlukan), dan reservoir distribusi. Dua hal yang harus diperhatikan pada sistem distribusi adalah tersedianya jumlah air yang cukup dan tekanan yang memenuhi, serta menjaga kualitas air yang berasal dari instalasi pengolahan.

Distribusi air minum dapat dilakukan dengan beberapa cara tergantung kondisi topografi yang menghubungkan sumber air dengan konsumen. Distribusi secara gravitasi, pemompaan maupun kombinasi pemompaan dan gravitasi dapat digunakan untuk mensuplai air ke konsumen dengan tekanan yang mencukupi (Al-Layla dkk., 1980 dan Peavy dkk., 1985).

Konsumen memerlukan sambungan air dengan tekanan yang cukup, dalam arti dapat dilayani dengan jumlah air yang diizinkan setiap saat. Untuk menjaga tekanan akhir pipa di seluruh daerah pelayanan, pada titik awal distribusi diperlukan tekanan yang lebih tinggi untuk mengatasi kehilangan tekanan karena gesekan, yang bergantung kecepatan aliran, jenis pipa, diameter pipa dan jalur pipa tersebut. Tekanan yang dibutuhkan pada titik awal distribusi tergantung pada: ketinggian bangunan tertinggi yang harus dicapai oleh air, jarak titik awal distribusi dari reservoir, tekanan untuk hidran kebakaran yang dibutuhkan. Alat pemadam kebakaran biasanya dilengkapi dengan pompa yang dapat menyedot air.

Daerah perumahan memiliki tekanan dalam pipa antara $1,8-2,8 \mathrm{~kg} / \mathrm{cm}^{2}$, daerah bisnis sekitar 5,3 kg/ $\mathrm{cm}^{2}$ sedangkan tekanan pelayanan untuk hidran kebakaran sebesar 4,2 $\mathrm{kg} / \mathrm{cm}^{2}$ (Al-Layla dkk.,1980). Kemudian, menurut Fair dkk.(1986), tekanan pada jalur pipa sekitar 20-40 psig (14-28 m), pada daerah bisnis sekitar $60-75$ psig $(42-53 \mathrm{~m})$ dan pada hidran kebakaran sekitar 45 psig $(32 \mathrm{~m})$ di ujung nozzle berdiameter $1 \frac{1}{8}$ inci. Tekanan dalam sistem distribusi dipertahankan dengan cara:

1. Meletakkan reservoir distribusi di tengah areal (secara tidak langsung akan mempengaruhi biaya maksimum untuk ukuran pipa). Ketika sistem disuplai dengan sistem pompa dan juga melalui reservoir, lokasi reservoir berada pada akhir dari sistem

2. Menyediakan reservoir penyeimbang (balancing reservoir), ketika suplai melebihi kebutuhan, air mengalir ke dalam tangki. Ketika kebutuhan melebihi suplai, air mengalir keluar dari reservoir penyeimbang melalui pipa. Ketika sistem distribusi didesain dengan sistem pompa, tangki penyeimbang diletakkan pada bagian akhir sistem.

Sistem jaringan distribusi didesain untuk membawa suatu kecepatan aliran tertentu. Kecepatan dalam pipa tidak boleh melebihi 0,6 $-1,2 \mathrm{~m} / \mathrm{dt}$. Ukuran pipa harus tidak melebihi dimensi yang diperlukan dan juga tekanan dalam sistem harus tercukupi. Dengan analisis jaringan pipa distribusi, dapat ditentukan dimensi atau ukuran pipa yang diperlukan sesuai dengan tekanan minimum yang diperbolehkan agar kuantitas aliran terpenuhi. (Al-Layla dkk., 1980).

\section{METODOLOGI}

Metode yang digunakan adalah Metode Tinjauan Langsung (Survey), Wawancara, dan Studi Literatur. Metode tinjauan langsung dimaksudkan untuk mengetahui secara langsung objek kajian serta mengetahui bagaimana pengelolaan dilaksanakan sesuai ketentuan yang disyaratkan. Metode Wawancara dilakukan untuk memperoleh informasi dengan cara mengadakan diskusi atau tanya jawab dengan responden atau pihak lain yang menguasai permasalahan yang ada. 
Metode Studi Literatur dilakukan dengan membaca literatur atau bibliografi yang ada di perpustakaan maupun bacaan yang terkait, sehingga dapat diperoleh data-data yang akurat dan dapat dipertanggung jawabkan (Indriantoro dan Supomo, 2009).

Teknik pengumpulan data yang digunakan adalah observasi atas pengelolaan sistem penyediaan air bersih, wawancara dengan pengelola dan pelanggan air bersih, dan dokumentasi atas pengelolaan air bersih. Data yang dikumpulkan bersifat kualitatif dan kuantitatif, meliputi data fisik wilayah, data sosial-ekonomi, dan data kondisi pengelolaan sistem penyediaan air bersih. Analisis data dilakukan secara deskriptif. Hasil analisis akan menggambarkan kondisi pengelolaan sistem penyediaan air bersih dan evaluasi berdasarkan standar, peraturan maupun studi literatur yang sesuai.

\section{PEMBAHASAN}

Sistem penyediaan air bersih adalah suatu sistem penyediaan air bersih yang meliputi pengambilan air baku, proses pengolahan dan reservoir serta distribusi (Depkimpraswil, 2002). Semua sistem penyediaan air bersih di Kota Madiun berasal dari sumur dalam yang didistribusikan langsung kepada pelanggannya sehingga sebagian besar pengelolaan air bersih di Kota Madiun meliputi sistem transmisi dan sistem distribusi.

\section{Evaluasi Sistem Transmisi PDAM Kota Madiun}

Lingkup dari sistem transmisi di PDAM Kota Madiun adalah dari sumber air baku menuju ke reservoir. Sistem transmisi pada PDAM Kota Madiun meliputi penyaluran air dari sumber air baku menuju ke reservoir. Sehingga hanya terdapat pada 2 lokasi, yaitu pada lokasi Ngrowo dan Kapuas. Sedangkan pada titik sumber air baku lain, tidak terdapat sistem transmisi karena dari sumur dalam langsung dipompa dan distribusikan ke pelanggan.

Pada lokasi Ngrowo jaringan pipa transmisi menghubungkan antara tujuh sumur ke dalam ground reservoir Ngrowo dan elevated reservoir Ngrowo. Keseluruhan panjang pipa transmisinya mencapai $980 \mathrm{~m}$. Pipa transmisi tersebut memiliki diameter $600 \mathrm{~mm}$ dengan jenis pipa yang berasal dari bahan ACP (Asbestos Cement Pipe).

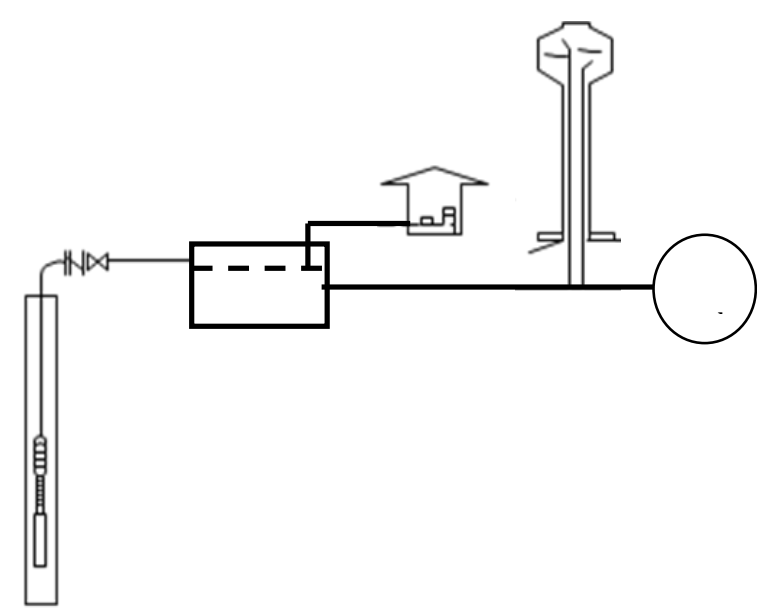

\section{Gambar 1. Profil Sistem Transmisi Ngrowo Sumber : PDAM Kota Madiun}

Sedangkan pada lokasi Kapuas jaringan transmisi menghubungkan 2 sumur yang terletak di Kapuas menuju ke elevated reservoir atau Menara Air Kapuas. Pipa transmisi tersebut berdiameter $350 \mathrm{~mm}$ dengan pipa berbahan ACP dan ductile.

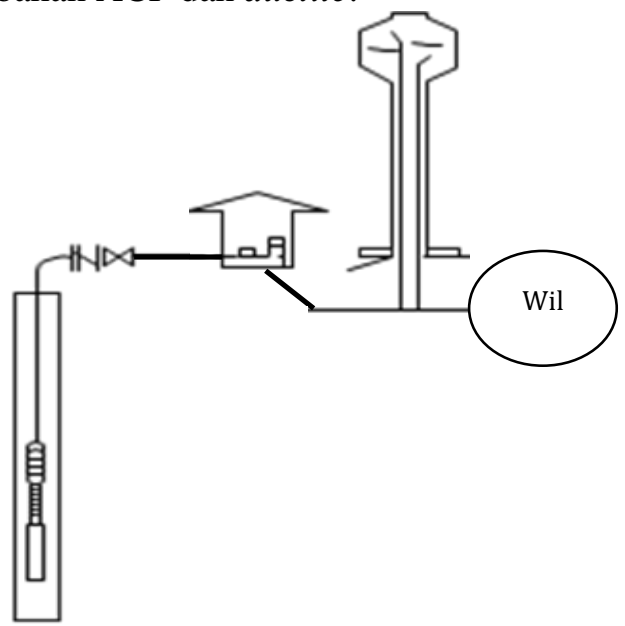

Gambar 2. Profil Sistem Transmisi Kapuas Sumber : PDAM Kota Madiun

Untuk lokasi sumur-sumur yang lain, air dari sumur dalam tersebut di injeksikan gas khlor dan langsung didistribusikan menuju ke pelanggan. 


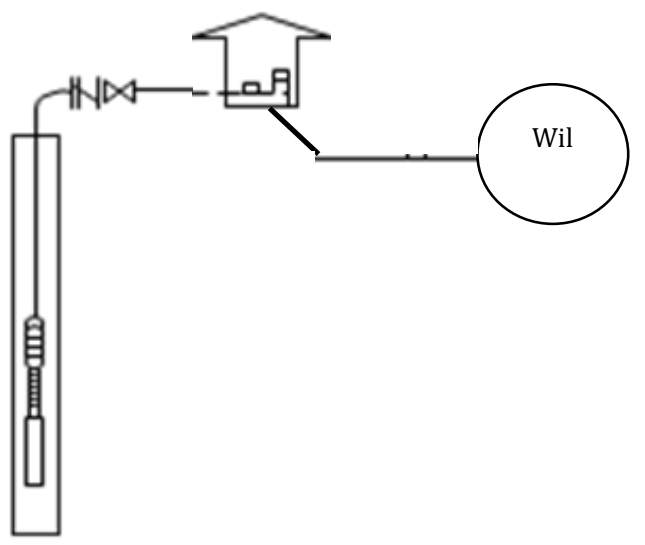

Gambar 3. Profil Sistem Penyaluran Air Langsung dari Sumur

Sumber : PDAM Kota Madiun

Sistem transmisi PDAM Kota Madiun dilakukan secara tertutup dengan sistem perpipaan. Pada sistem ini, aliran tidak tergantung pada profil tanah. Kualitas air tidak mudah di pengaruhi faktor dari luar selain itu operasi dan pemeliharaannya mudah, walaupun biaya pembuatannya lebih mahal jika dibandingkan dengan sistem terbuka dan sistem tertutup. Jadi sistem perpipaan dinilai cukup aman dan merupakan sistem yang sesuai diterapkan dalam sistem transmisi yang ada di PDAM Kota Madiun karena dapat menyalurkan air dengan kecepatan tinggi dan dapat dioperasikan tanpa gangguan.

Pengaliran air di mulai dari sumur menuju ke reservoir dengan sistem perpipaan yang berada di bawah permukaanan tanah. Sistem transmisi tersebut terdapat di kawasan PDAM Ngrowo. Sedangkan untuk sumursumur yang letaknya diluar kawasan PDAM Ngrowo, penyaluran air sistem perpipaan namun langsung menuju ke pipa distribusi. Sistem pengaliran sumber air ini berlangsung disetiap sumur dalam yang ada di Kota Madiun. Masing masing sumur mempunyai kapasitas produksi yang berbeda, sehingga masingmasing pipa yang mengalirkan air dari sumur menuju ke sistem distribusinya juga berbeda ukurannya. Berikut ini adalah data kapasitas produksi sumur dalam yang ada di Kota Madiun.
Tabel 1. Kapasitas Produksi Sumur Dalam Sumber : PDAM Kota Madiun

\begin{tabular}{|c|l|c|c|}
\hline \multirow{2}{*}{ No } & \multirow{2}{*}{$\begin{array}{c}\text { Nama } \\
\text { Instalasi }\end{array}$} & Tahun & $\begin{array}{c}\text { Kap. } \\
\text { Sumur }\end{array}$ \\
\cline { 3 - 4 } & & Pemasangan & lt /s \\
\hline 1 & Ngrowo 1 & 2008 & 40 \\
\hline 2 & Ngrowo 2 & 1996 & 40 \\
\hline 3 & Ngrowo 3 & 1999 & 40 \\
\hline 4 & Ngrowo 4 & 1985 & 30 \\
\hline 5 & Ngrowo 5 & 1996 & 30 \\
\hline 6 & Ngrowo 6 & 1999 & 40 \\
\hline 7 & Ngrowo 7 & 2006 & 40 \\
\hline 8 & Kapuas I & 1974 & 40 \\
\hline 9 & Kapuas II & 2004 & 40 \\
\hline 10 & Perumnas Ia & 2002 & 40 \\
\hline 11 & Perumnas Ib & 2003 & 30 \\
\hline 12 & Perumnas IIa & 2007 & 40 \\
\hline 13 & Perumnas IIb & 1996 & 30 \\
\hline 14 & P2AT & 1974 & 30 \\
\hline 15 & Banjarejo & 2000 & 40 \\
\hline 16 & Sidomakmur I & 2005 & 40 \\
\hline 17 & Sidomakmur & & \\
\hline 18 & II & 2006 & 40 \\
\hline 19 & Ngebong I & 2006 & 40 \\
\hline 20 & Kelun & 1995 & 30 \\
\hline 21 & Tawang rejo & 2007 & 40 \\
\hline & & & \\
\hline
\end{tabular}

Penentuan jalur pipa transmisi pada umumnya ditentukan dengan cara mengikuti jalur jalan raya dan memilih jalur aman yang tidak memerlukan banyak perlengkapan. Jalur pipa transmisi yang dimiliki PDAM Kota Madiun cukup sederhana, sehingga mudah dalam penentuan dan pemeliharaannya. Untuk lokasi Ngrowo jalur pipa transmisi menghubungkan 7 sumur dalam menuju ke dalam ground reservoir Ngrowo. Penentuan jalur sudah sesuai dengan kriteria dan kondisi lokasi sistem transmisi. Dimana dari masingmasing sumber air baku tersebut pipa transmisi menyalurkan air menuju bak penampung tanpa terdapat jalur cabang atau sadapan air lainnya. Jalur yang dibuat telah mempertimbangan efisiensi pipa, sehingga dibuat lurus langsung menuju lokasi penampungan. 
Untuk penanaman pipa transmisi telah mengikuti standar dari Dirjen Cipta Karya yaitu dipasang di dalam tanah dengan kedalaman 80 $\mathrm{cm}$.

Untuk tipe pengalirannya menggunakan sistem pemompaan. Pompa digunakan untuk meningkatkan tekanan yang diperlukan untuk mengambil air dari sumber dan disalurkan melalui pipa menuju ke reservoir. Cara ini sudah sesuai, melihat kondisi topografi di lokasi sumber dan letak reservoirnya yang cukup landai (ketinggian $63-65 \mathrm{dpl}$ ) sehingga membutuhkan pompa untuk menyalurkan air. Pengaliran air di mulai dari sumur menuju ke reservoir. Sistem transmisi tersebut terdapat di kawasan PDAM Ngrowo. Sedangkan untuk sumur-sumur yang letaknya diluar kawasan PDAM Ngrowo, penyaluran airnya juga secara tertutup, sistem perpipaan, namun langsung menuju ke pipa distribusi. Sistem pengaliran sumber air ini berlangsung disetiap sumur dalam yang ada di Kota Madiun. Berikut ini adalah data kapasitas produksi yang ada di Kota Madiun.

\section{Evaluasi Perlengkapan Sistem Transmisi}

Perlengkapan penting dan pokok dalam sistem transmisi antara lain katup udara (Air Valve), Stop/Gate Valve, penguras (Blow Off), perkakas (Fitting) dan Blok Beton. Analisis terhadap perlengkapan sistem transmisi perlu dilakukan karena kondisi operasional pengaliran yang baik memerlukan dukungan perlengkapan yang memadai. Dalam evaluasi perlengkapan ini beberapa hal yang berkaitan dengan perlengkapan sistem transmisi yang kurang sesuai dengan ketentuan SOP Unit Transmisi PDAM Kota Madiun, antara lain:

\section{Katup udara (air valve)}

Katup udara yang berfungsi melepaskan udara yang terakumulasi dalam pipa transmisi ini sudah berlumut dan mengeluarkan air. Padahal seharusnya pada katup udara tidak teraliri oleh air. Apabila dalam katup tersebut justru mengeluarkan air maka fungsi sebagai pelepas udara tidak dapat terjadi dalam katup udara tersebut.

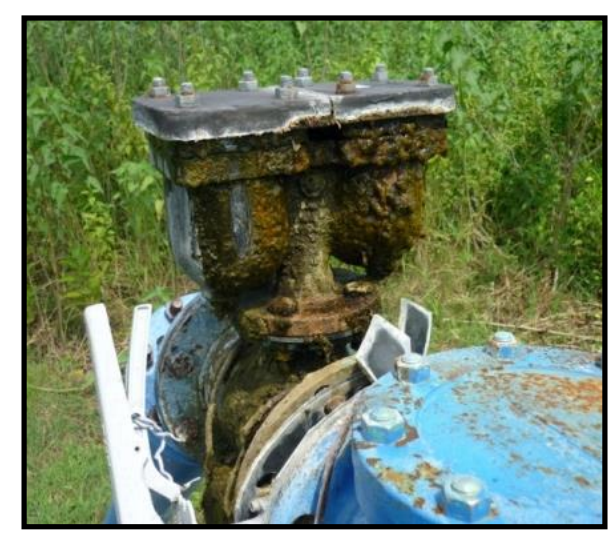

Gambar 4. Katup Pelepas Udara

\section{Pipa Transmisi}

Terdapat pipa transmisi yang sudah mengelupas sehingga dikhawatirkan dapat terjadi kebocoran.

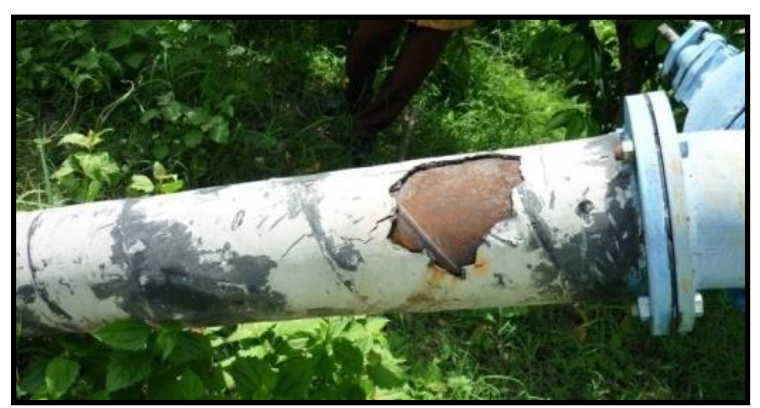

Gambar 5. Kondisi Pipa pada Head Pompa

\section{Alat Pengukur Tekanan}

Salah satu sumur pompa, alat pengukur tekanan airnya sudah tidak berfungsi lagi. Kacanya pecah, berkarat dan tidak dapat digunakan untuk mengukur tekanannya.

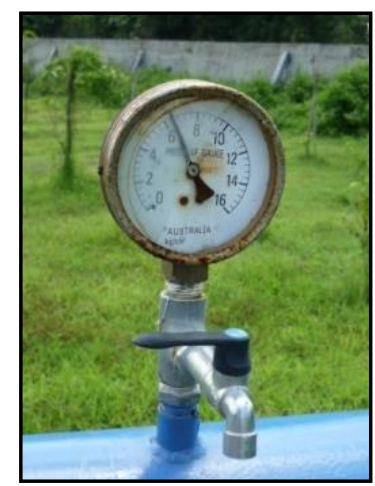

Gambar 6. Alat Pengukur Tekanan Air

\section{Evaluasi Reservoir}

Reservoir air baku dibuat untuk menyesuaikan antara debit pipa transmisi yang konstan dengan debit yang masuk ke instalasi pengolahan air bersih yang berfluktuasi. 
Reservoir ini juga berfungsi untuk menjaga kesetimbangan antara produksi dengan kebutuhan, sebagai penyimpan kebutuhan air untuk keperluan instalasi. Dalam pengelolaannya sistem transmisi juga mencakup reservoir induk yang digunakan sebagai bak penampung air yang berasal dari sumur-sumur dalam di sekitar reservoir.

PDAM Madiun memiliki 3 buah reservoir yang terdiri 2 reservoir atas (elevated reservoir ) dan 1 reservoir induk (ground reservoir). Ketiga reservoir tersebut adalah:

\section{Ground Reservoir Ngrowo}

Reservoir kantor PDAM Ngrowo terletak di Jalan Pesanggrahan dengan reservoir berbentuk balok dan memiliki kapasitas $750 \mathrm{~m}^{3}$. Ground Reservoir ini disuplai dari 7(tujuh) sumur dalam yang berkapasitas total 162,3 lt/detik. Bangunan fisik reservoir masih terawat dengan baik. Reservoir ini dilengkapi dengan sistem pembubuh bahan kimia, desinfektan gas khlor, yang cukup baik. Secara keseluruhan kinerja operasional reservoir ini masih cukup baik dalam mendistribusikan air bersih.

\section{Elevated Reservoir Ngrowo}

Menara air Ngrowo juga terletak di kawasan PDAM Ngrowo, di Jalan Pesanggrahan dengan reservoir berbentuk silinder dengan kapasitas sebesar $750 \mathrm{~m}^{3}$. Pasokan air yang menuju menara ini berasal dari ground reservoir Ngrowo. Fungsi utama untuk kepentingan distribusi air. Selain itu juga sebagai penampung air kedua setelah ground reservoir Ngrowo. Secara keseluruhan kinerja reservoir ini cukup baik dan kokoh dengan ketinggian mencapai $95,5 \mathrm{~m}$.

\section{Elevated Reservoir Kapuas}

Menara air Kapuas terletak di Jalan Kapuas dengan reservoir berbentuk silinder di atas menara dengan kapasitas $600 \mathrm{~m}^{3}$. Menara air ini disuplai oleh sumur dalam Kapuas 1 dan sumur dalam Kapuas 2. Tinggi reservoir mencapai 95 m. Waktu operasional reservoir Kapuas adalah 20 jam, terdiri dari pukul $07.00-21.00$ dan pukul 03.00-07.00. Secara keseluruhan kinerja reservoir ini cukup baik. Sebenarnya pada bangunan menara air Kapuas ini juga dilengkapi pengolahan air yang dulu dibuat oleh Belanda. Namun karena kini PDAM Madiun menggunakan metode pengolahan air dengan cara desinfeksi, maka bangunan tersebut tidak difungsikan dan ditambah bangunan penginjeksi gas khlor yang disuntikkan ke dalam 2 sumur dalam Kapuas.

\section{Evaluasi Sistem Distribusi PDAM Kota Madiun}

Sistem distribusi air bersih PDAM Kota Madiun adalah pendistribusian air melalui sistem perpipaan dari bangunan reservoir ke daerah pelayanan. Dalam sistem distribusi beberapa faktor yang perlu diperhatikan antara lain ; daerah layanan dan jumlah penduduk yang akan dilayani, tipe pengaliran dan pola jaringan distribusi, penentuan jalur distribusi, panjang dan diameter pipa distribusi, durasi pelayanan, tekanan air, perlengkapan sistem distribusi serta tingkat kebocoran air.

Sistem jaringan pipa distribusi yang digunakan adalah sistem jaringan kombinasi (grade system) antara sistem jaringan tertutup (loop) dengan sistem jaringan distribusi bercabang (dead-end distribution system). Bentuk jaringan pipa distribusi tersebut ditentukan oleh kondisi topografi Kota Madiun yang relatif datar, lokasi reservoir, luas wilayah pelayanan dan jumlah pelanggan yang cukup banyak. Evaluasi sistem distribusi difokuskan pada hal-hal pokok yang menjadi kendala pelayanan air bersih di Kota Madiun. Beberapa hal tersebut antara lain daerah pelayanan, durasi layanan, tekanan air di wilayah distribusi dan operasional pompa.

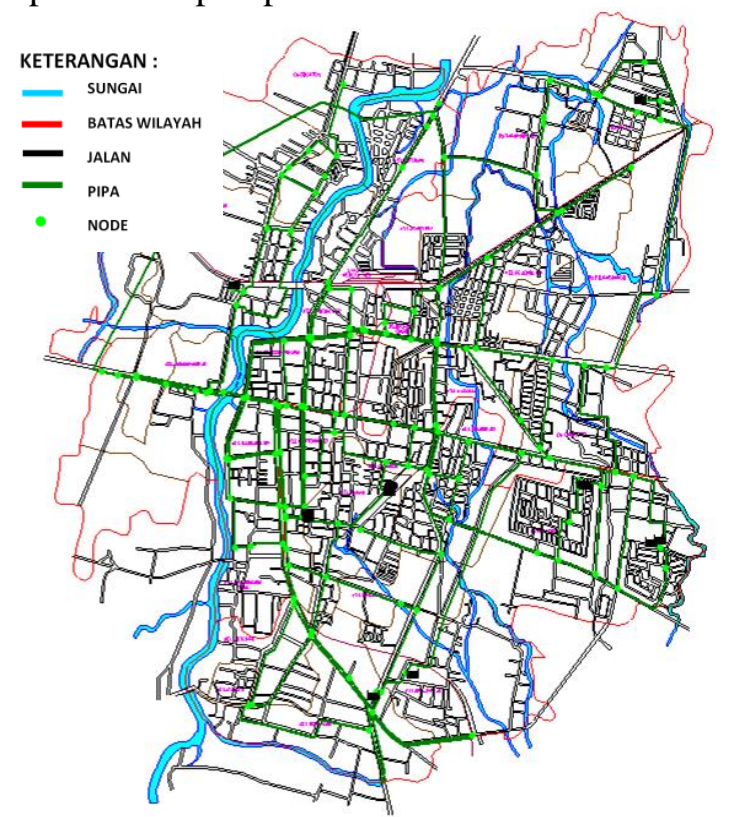

Gambar 7. Jaringan Distribusi PDAM Kota Madiun 
Sistem pemompaan digunakan apabila beda tinggi antara sumber air baku dengan wilayah pelayanan sangat kecil atau wilayah yang dilalui oleh jalur perpipaan berada di atas sumber air terutama di wilayah yang dilayani dari sumur dalam. Kota Madiun memiliki elevasi tanah yang landai sehingga sistem pemompaan merupakan penyelesaian terbaik pada sistem distribusi air bersih. Sistem distribusi cara melingkar merupakan sistem distribusi air baku dari sumber air, disadap dan diendapkan kemudian melalui pipa hantar air baku tersebut masuk bagian pengolahan, air bersih hasil pengolahan ditampung dalam reservoir dan air bersih siap didistribusikan melalui pipa induk lingkaran dan pipa induk cabang. Jaringan pipa distribusi menggunakan jenis pipa PVC. Kondisi pipa distribusi sebagian besar baik.

Bentuk jaringan pipa distribusi tersebut ditentukan oleh kondisi topografi Kota Madiun yang relatif datar, lokasi reservoir, luas wilayah pelayanan dan jumlah pelanggan yang cukup banyak. Evaluasi sistem distribusi difokuskan pada hal-hal pokok yang menjadi kendala pelayanan air bersih di Kota Madiun. Beberapa hal tersebut antara lain daerah pelayanan, durasi layanan, tekanan air di wilayah distribusi dan operasional pompa

\section{Evaluasi Tekanan Air}

Hasil uji tekanan air dalam pipa yang di dapat dari data PDAM Kota Madiun untuk daerah distribusi Ngrowo adalah tekanan maksimum $24 \mathrm{~m}$, tekanan minimum $10 \mathrm{~m}$ dan tekanan rata-rata adalah $15 \mathrm{~m}$. Untuk daerah distribusi Kapuas tekanan maksimum mencapai $33 \mathrm{~m}$, tekanan minimum saat operasional $12 \mathrm{~m}$ dengan rata-rata tekanan berkisar antara $18 \mathrm{~m}$. Jika dilihat dari nilai tekanan rata-ratanya, nilai ini telah memenuhi tekanan minimum yang disyaratkan Kementerian PUPR yaitu sebesar $15 \mathrm{~m}$. Namun jika dilihat dari kondisi tekanan minimumnya belum memenuhi standar yang telah ditetapkan Departemen PU (Dinas PU, 1991).

Hasil uji tekanan air tersebut tidak dapat disimulasikan secara keseluruhan dengan program Epanet versi 2.0. Karena tidak adanya penerapan zona dan masing-masing sumber air baku menyebar melayani kebutuhan air di wilayah sekitar lokasi sumber sehingga sulit terdeteksi. Apabila dilakukan pengambilan uji salah satu lokasi sumber (Sumur Kelun, gambar
8) hasil tekanan perhitungan tekanan air oleh program Epanet adalah sebagai berikut ; tekanan maksimum $60,37 \mathrm{~m}$, tekanan minimum $6,23 \mathrm{~m}$ dan tekanan rata-rata $25,52 \mathrm{~m}$. Untuk hasil uji tekanan dengan program Epanet di wilayah sumur kelun rata-rata tekannya telah memenuhi standar Departemen PU, tetapi tekanan minimum tidak memenuhi standar.

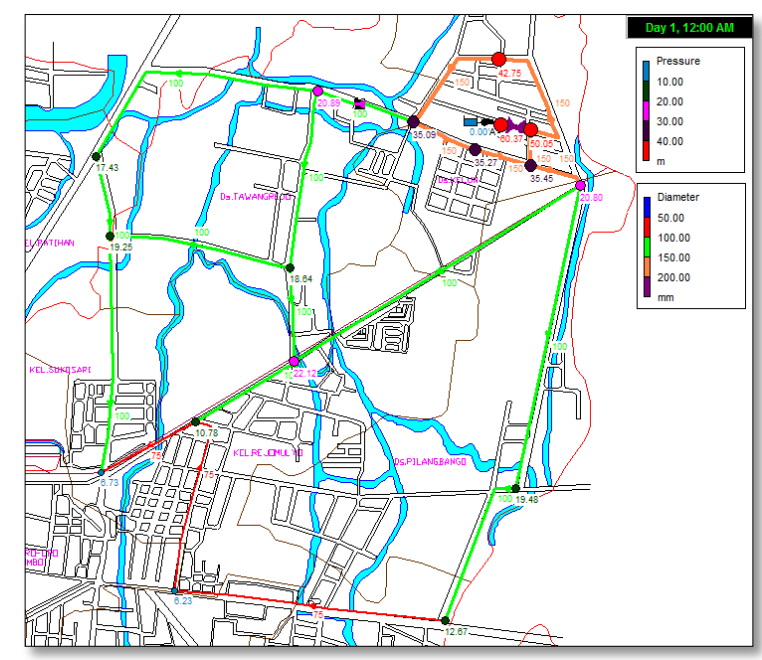

Gambar 8. Simulasi Epanet Kelun

Perbedaan hasil uji tekanan yang dilakukan di lapangan dengan perhitungan Epanet dapat disebabkan oleh beberapa faktor. Faktor- faktor tersebut diantaranya adalah:

1. Adanya kebocoran pada jaringan perpipaan

Pada perhitungan Epanet, faktor kebocoran dapat diabaikan sehingga nilai sisa tekan tidak berubah. Sedangkan pada kenyataan di lapangan menunjukkan bahwa adanya kebocoran dapat menyebabkan pengurangan sisa tekan di wilayah distribusi.

2. Umur jaringan perpipaan yang digunakan

Jaringan perpipaan yang digunakan oleh PDAM saat ini telah banyak yang berumur lebih dari 10 (sepuluh) tahun. Faktor umur pipa berpengaruh pada koefisien Hazen-Williams. Hal ini akan menyebabkan kekasaran pipa bertambah sehingga kecepatan aliran dalam pipa berkurang. Sedangkan pada perhitungan Epanet, koefisien Hazen Williams dianggap tetap sesuai dengan jenis pipa yang digunakan sehingga aliran dalam pipa dianggap tidak berubah.

\section{Evaluasi Perpipaan}

Pipa yang digunakan dalam sistem distribusi PDAM Kota Madiun adalah pipa PVC dan DCIP. Pipa DCIP digunakan untuk 
membawa sejumlah besar air dari instalasi pemompaan ke dan dari reservoir distribusi menuju daerah pelayanan. Sedangkan untuk pelayanan langsung ke konsumne menggunakan pipa PVC. Pipa ini lebih fleksibel daripada yang lain dan mudah penyambungannya.

Pada penentuan jalur pipa ditentukan dengan cara mengikuti jalur jalan raya. Penentuan jalur sudah sesuai dengan kriteria dan kondisi wilayah pelayanan air bersih. Untuk penanaman pipa distribusi telah mengikuti standar dari Dirjen Cipta Karya yaitu dipasang di dalam tanah dengan kedalaman 80 $\mathrm{cm}$ untuk pipa di jalur biasa dan $100 \mathrm{~cm}$ untuk pipa dijalur bawah jalan raya.

Beberapa perlengkapan pipa distribusi antara lain standmeter (meter air), alat pengukur tekanan air, valve, pengguras dan berbagai aksesoris pipa seperti bend, tee, sok dan fleng. Dalam evaluasi perlengkapan ini perlengkapan distribusi yang tidak terawat dan terpelihara adalah alat Pengukur Tekanan Distribusi. Kondisi alat pengukur tekanan disalah satu pipa distribusi tepatnya di jalan sudirman, kacanya pecah dan berkarat.

\section{Evaluasi Daerah dan Durasi Pelayanan}

Pembagian daerah pelayanan di PDAM

Kota Madiun belum dapat menerapkan zonazona pelayanan (sistem zoning) di lapangan. Penerapan zone pelayanan ini sulit dilaksanakan karena banyak sumur dalam yang langsung difungsikan sebagai pemasok air tanpa melewati reservoir distribusi. Hal ini yang menyebabkan kesulitan pelaksanaan zoning pelayanan. Selain itu terdapat pipa distribusi yang terpasang ganda, ada dua atau lebih saluran pipa dalam satu jalur. Hal ini disebabkan karena banyaknya saluran pipa PDAM peninggalan Belanda yang sudah rusak namun tidak dibongkar melainkan membuat jalur baru, sehingga mempersulit penetapan zoning pemasokan air di suatu wilayah.

PDAM Kota Madiun melayani 31.588 pelanggan, dengan jumlah SR adalah 30.512 unit dan HU 45 unit. Dari hasil analisis dan perhitungan, tingkat pelayanan mencapai 60,98 $\%$ sehingga untuk saat ini belum memenuhi target MDGs yaitu $80 \%$. Selain jaringan pipa, sistem distribusi juga menyangkut tentang cakupan pelayanannya. Daerah pelayanan PDAM Kota Madiun yaitu kecamatan Taman, Manguharjo dan Kartoharjo. Berdasarkan data cakupan pelayanan PDAM Kota menunjukkan bahwa jumlah Sambungan Rumah (SR) sebanyak 30.512 sambungan dan Hidran Umum (HU) sebanyak 45 unit.

Sistem distribusi air bersih memiliki durasi pelayanan yang berbeda di setiap daerah pelayanan. Hal ini disebabkan oleh perbedaan kemampuan sumber air baku yang menyuplai kebutuhan air bersih pelanggan. Durasi pelayanan air bersih PDAM Kota Madiun berkisar antara 9 jam hingga 24 jam. Durasi pelayanan terpendek $(9$ jam $)$ dialami oleh daerah pelayanan dengan sumber air baku yang berasal dari sumur dalam Tawang Rejo. Besarnya durasi pelayanan tersebut masih mencukupi dan memenuhi kebutuhan air baku penduduk Kota Madiun yang terlayani oleh PDAM.

\section{Evaluasi Tingkat Kebocoran}

Tingkat kebocoran terdiri atas kebocoran fisik dan kebocoran administrasi. Kebocoran fisik disebabkan oleh kerusakan pada jalur perpipaan. Sedangkan kebocoran administrasi disebabkan oleh kesalahan pembacaan meter, kerusakan water meter, sambungan liar dan operasional. Pada umumnya kebocoran ini disebabkan oleh:

1. Kondisi meter air pelanggan yang telah habis umur teknisnya (diatas 4 tahun) dan meter air tidak akurat sebelum habis usia pakainya.

2. Illegal connection/sambungan liar dan pencurian air baik yang dilakukan melalui pipa primer/sekunder/tertier maupun penyadapan sebelum meter.

3. Pembacaan meter yang tidak akurat, tidak dibaca maupun kesalahan input data akibat meter rusak/buram/tertimbun/rumah terkunci (kosong)/pembacaan oleh pelanggan/stand meter mundur maupun human error operator.

4. Lemahnya penegakan hukum terhadap pelanggan yang menunggak di atas 3 bulan.

5. Meter air dirusak sehingga tidak berfungsi sebagaimana mestinya atau registernya (meter tempered).

6. Penutupan sambungan pelanggan baik sementara maupun permanen yang tidak sempurna.

7. Kebocoran fisik pada pipa-pipa dinas, titik tapping maupun peralatannya.

8. Banyak pipa tua berbahan cast iron yang korosif dan rawan kerusakan akibat 
keasaman tanah yang tinggi maupun lahan gambut.

9. Belum sepenuhnya dijalankan program distrik metering zone (DMZ) dan Pressure Management.

Kerugian yang ditimbulkan oleh kebocoran air adalah sebagai berikut :

1. Penurunan kuantitas air yang dapat didistribusikan ke ke pelanggan

2. Penurunan kualitas air akibat terjadinya kontaminasi

3. Penurunan tekanan air di wilayah distribusi

4. Penurunan pendapatan yang diterima oleh PDAM

Untuk mengurangi besarnya kehilangan air yang terjadi maka perlu diusahakan langkahlangkah pencegahan kehilangan air sebagai berikut:

\section{1) Monitoring kebocoran}

Monitoring kebocoran ini dimaksudkan untuk mengetahui terjadinya kebocoran sedini mungkin sehingga kebocoran yang akan terjadi dapat dicegah. Ini dapat dilakukan dengan pemantauan terhadap sistem penyediaan air bersih yang rawan terhadap kebocoran. Monitoring kebocoran juga dapat mengetahui secara cepat apabila terjadi kebocoran sehingga dapat segera melakukan perbaikan. Monitoring dilakukan dengan mengadakan pemantauan pada jaringan perpipaan.

2) Rehabilitasi pipa dan perlengkapan

Perpipaan dan perlengkapannya yang sudah tua dan tidak memenuhi standar seharusnya dapat segera diperbarui karena sangat rawan untuk terjadinya kebocoran. Ini juga dapat dilakukan dengan memperbaiki pemasangan perpipa an yang kurang sempurna.

3) Meterisasi

Meterisasi yaitu melakukan perbaikan meteran yang sudah tidak berfungsi dengan baik. Yang paling penting adalah standarisasi nilai meteran sehingga meteran air tersebut sesuai dengan standar dalam pembacaannya.

\section{SIMPULAN}

Mekanisme pengelolaan sistem penyediaan air bersih di PDAM Kota Madiun meliputi sistem transmisi, reservoir dan sistem distribusi. Evaluasi sistem transmisi dan distribusi yang terdapat di PDAM Kota Madiun antara lain; kondisi sistem transmisi yang kurang baik karena tidak terdapat jalur atau skema sistem transmisi yang jelas dan pemeliharaannya tidak terawasi secara keseluruhan. Kapasitas reservoir yang dimiliki PDAM Kota Madiun sudah mencukupi untuk kebutuhan tampungan dan penyediaan air bersih. Sistem distribusi PDAM Kota Madiun belum dapat menerapkan zona-zona pelayanan (sistem zoning) di lapangan karena beberapa sumur dalam langsung difungsikan sebagai pemasok air menuju daerah di sekitar lokasi sumur. Permasalahan tekanan air kurang diperhatikan sehingga dibeberapa wilayah pelayanan tekanan air masih kurang.

\section{UCAPAN TERIMA KASIH}

Terimakasih kepada segenap karyawan dan keluarga besar PDAM Kota Madiun atas kerjasama dan bantuannya selama penelitian berlangsung.

\section{DAFTAR PUSTAKA}

Al-Layla, M.A., 1980., Water Supply Engineering Design, $3^{\text {rd }}$ Edition, Ann Arbor Science Publishers, Inc., Michigan, USA.

Departemen Kimpraswil, 2002, Pedoman atau Petunjuk Teknis dan Manual, Bagian 6, Sistem Penyediaan Air Minum Perkotaan, Departemen Permukiman dan Prasarana Wilayah, Jakarta.

Departemen Pekerjaan Umum DJCK Direktorat Bina Program, 1991, Diseminasi: Petunjuk Teknis Kerangka Dasar PJMP3KT Kota Sedang dan Kecil dan Petunjuk Teknis Penganggaran Proyek Bantuan Pusat, Buku I, Departemen Pekerjaan Umum, Jakarta.

Fair, Geyer \& Okun. 1986. Water and Wastewater Engineering. Vol II, John Wiley and Sons Inc., New York.

Indriantoro, N. dan Supomo, B., 2009, Metodologi Penelitian Bisnis Untuk Akuntansi Manajemen. Yogyakarta. BPFE Yogyakarta, Edisi Pertama.

Peavy, H., 1985, Environmental Engineering. Prentice-Hall International, Singapua.

Peraturan Menteri Pekerjaan Umum Nomor 122 Tahun 2015 Tentang Sistem Penyediaan Air Minum. 